\title{
Developmental Landmarks and the Warnock Report: A Sociological Account of Biological Translation
}

\author{
SARAH FRANKLIN \\ Reproductive Sociology Research Group (ReproSoc), University of Cambridge
}

As the global in vitro fertilization (IVF) industry enters its fifth decade, the complex legacies of this multi-billion-dollar biomedical sector increasingly repay careful sociological and historical study. Despite its central role as the platform technology facilitating several of the most important bioscientific innovations of the past fifty years, including cloning, stem cells, and cybrids, IVF's significance as one of the twentieth century's most disruptive technologies remains curiously overlooked. ${ }^{1}$ Not only commercially, but socially and politically, IVF has proven far more transformative than many anticipated: the normalization of IVF has contributed to widespread changes in attitudes

Acknowledgments: This research was supported by the Wellcome Trust, the British Academy, the Economic and Social Research Council, and the University of Cambridge. The author would like to thank the members of the Reproductive Sociology Research Group (ReproSoc) at Cambridge and the CSSH reviewers for their careful and instructive feedback. I also thank Roseanne Pratt of the Department of Health Repository in Burnley, Lancashire, for her help. All images are reproduced with permission of the Department of Health Repository.

${ }^{1}$ A growing literature surrounds the development of IVF by individuals directly involved in its history as either scientists or policy makers: e.g., Kay Elder and Martin H. Johnson, "The Oldham Notebooks: An Analysis of the Development of IVF 1969-1978," Reproductive Biomedicine \& Society Online 1, 1 (2015): 3-8; Ruth Deech and Anna Smajdor, From IVF to Immortality: Controversy in the Era of Reproductive Technology (Oxford University Press, 2007). Journalists have also contributed: e.g., Liza Mundy, Everything Conceivable: How the Science of Assisted Reproduction Is Changing Our World (Knopf, 2007); Miriam Zoll, Cracked Open: Liberty, Fertility, and the Pursuit of High-Tech Babies (Interlink Books, 2013). Few scholarly studies, however, analyze IVF as a disruptive or translational technology in broader socioeconomic terms; see Susan Merrill Squier, Babies in Bottles: Twentieth-Century Visions of Reproductive Technology (Blackwell, 1994); Charis Thompson Making Parents: The Ontological Choreography of Reproductive Technologies (MIT Press, 2005); Sarah Franklin, Biological Relatives: IVF, Stem Cells, and the Future of Kinship (Duke University Press, 2013). 
toward parenting, kinship, and family, ${ }^{2}$ new "repronational" agendas in many states across the world, ${ }^{3}$ distinctive forms of bioeconomy, ${ }^{4}$ and a complex geography of cross-border reproductive transactions. ${ }^{5}$ In contrast to the widespread expectation in the 1990s that the Human Genome Project would be the biological behemoth that would pose the most significant ethical and legal challenges for biomedicine in the new millennium, early twenty-first-century public and political debate has been far more concerned with breakthrough applications from developmental and reproductive biology such as cloned animals, artificial gametes, and immortal cell lines, as well as controversies over surrogacy, third-party gamete donation, and egg freezing. ${ }^{6}$

The lack of attention to IVF's transformative impact on society, biology, and technology is especially notable given the increasing emphasis on "translational" bioscience during exactly the same period during which IVF gained prominence. ${ }^{7}$ The analysis offered here thus begins from the premise that IVF was one of the last century's most significant translational technologies, but that its translational importance is under-theorized and that we are missing some of its vital sociological and historical lessons as a result. Whereas conventional definitions of biomedical translation emphasize bench-to-bedside or research-into-practice flows of knowledge, the history of IVF, and in particular its social legacy in the form of governance of new biotechnologies, open up new perspectives on what is meant by "biological translation," or "translational knowledge," pointing to a wider range of translational

2 Marilyn Strathern, Reproducing the Future: Anthropology, Kinship, and the New Reproductive Technologies (Manchester University Press, 1992); Susan Golombok, Modern Families: Parents and Children in New Family Forms (Cambridge University Press, 2015); Petra Nordqvist and Carol Smart, Relative Strangers: Family Life, Genes and Donor Conception (Palgrave Macmillan, 2014).

3 Sarah Franklin and Marcia Inhorn, "IVF Global Histories," Reproductive Biomedicine and Society Online 2 (2016): 1-7.

4 Debora L. Spar, The Baby Business: How Money, Science, and Politics Drive the Commerce of Conception (Harvard University Press, 2005); Melinda E. Cooper, Life as Surplus: Biotechnology and Capitalism in the Neoliberal Era (University of Washington Press, 2008); Melinda Cooper and Catherine Waldby, Clinical Labour: Tissue Donors and Research Subjects in the Global Bioeconomy (Duke University Press, 2014).

5 Marcia Inhorn and Zeynep Gurtin, "Cross-Border Reproductive Care," Reproductive Biomedicine Online 23, 5 (2011): 665-76.

6 Jane Maienschein, Whose View of Life? Embryos, Cloning, and Stem Cells (Harvard University Press, 2003); Sarah Franklin, Dolly Mixtures: The Remaking of Genealogy (Duke University Press, 2007).

7 "Translational" is a millennial policy term referring to the derivation of clinical benefit from publicly funded science (e.g., David Cooksey, "A Review of UK Health Research Funding," Her Majesty's Stationery Office, 2006). This managerial definition of translation was introduced to accelerate the development of "useful" and profitable clinical applications from basic science; e.g., Cambrosio et al., "Mapping the Emergence and Development of Translational Cancer Research," European Journal of Cancer 42, 18 (2007): 3140-48. 
actors and a greater range of translational activities that extend well beyond the laboratory. ${ }^{8}$

"Translational" science, biomedical "translation," and the emergence of a "translational imperative" within science policy all refer to a top-down, goaloriented, and tax-payer-accountability driven model of promoting useful and profitable applications from basic science. As Wainwright et al. summarize this shift, "translational" signifies "expectations about the trajectory from bench to bedside." ${ }^{9}$ However, a major feature of the literature on translation, from both within and outside the lab, is an emphasis on failure. As the same authors go on to claim, "The complex cloth of translational research is a difficult thing to keep from unravelling, as our scientists seem only too aware."10

IVF's history as a translational technology confirms many of the findings of sociologists of translational science in showing how it nearly failed to achieve clinical, legal, or political viability. However, it also offers the opportunity to broaden the definition of what counts as translational success, and in particular the importance to this process of social consensus. Effective regulation of IVF and human embryo research, based on repeated and often lengthy periods of public and parliamentary debate, has proven critical to the ability of successive UK governments to support bio-innovation environments that are progressive and inclusive, but also stable and predictable. This combination is considered vital to the success of contemporary fields of biomedical translation such as tissue engineering and regenerative medicine. ${ }^{11}$ As the postmillennial global pattern has repeatedly confirmed, long-term success in maintaining the social consensus conducive to a stable context of bioinnovation is both a difficult and rare achievement. Moreover, as we have seen in heated and often highly polarized debates over controversial techniques such as cloning and stem cells (and more recently CRISPR), the governance of human reproductive engineering raises fundamental issues related to family,

8 For classic sociological accounts of biomedical "translation," see Joan H. Fujimura, Crafting Science: A Sociohistory of the Quest for the Genetics of Cancer (Harvard University Press, 1992); Ilana Löwy, Between Bench and Bedside: Science, Healing, and Interleukin-2 in a Cancer Ward (Harvard University Press, 1997); or Susan Leigh Star and James Griesemer, "Institutional Ecology, 'Translations' and Boundary Objects," Social Studies of Science 19 (1989): 387-420. For more recent accounts, see Peter Keating and Alberto Cambrosio, Biomedical Platforms: Realigning the Normal and the Pathological in Late-Twentieth-Century Medicine (MIT Press, 2006); Kaushik Sunder Rajan and Sabina Leonelli, "Biomedical Trans-actions, Postgenomics, and Knowledge/Value,” Public Culture 25, 3 (2013): 463-75.

9 Steven P. Wainwright et al., "From Bench to Bedside? Biomedical Scientists' Expectations of Stem Cell Science as a Future Therapy for Diabetes," Social Science \& Medicine 63, 8 (2006): 2052-64.

10 Ibid., 2062.

11 David Willetts, “Eight Great Technologies” (UK Government, 2013), at: https://www.gov.uk/ government/speeches/eight-great-technologies (accessed 21 May 2019); John Gardner et al., "Promissory Identities: Sociotechnical Representations and Innovation in Regenerative Medicine," Social Science and Medicine 174 (2017): 70-78. 
gender, parenting, healthcare, religion, law, and human rights that make it highly unpredictable and volatile. This is why the complex moral, ethical, and affective shifts that enabled the first successful comprehensive legislation of human fertilization and embryology in the UK between 1982 and 1990, and the ensuing model of translating biological facts into legal limits that is now the de facto global standard, continue to repay careful study. We need to pay particular attention to the sociological foundations of successful governance of reproductive medicine-where it exists-both because this dimension of "translation" has been overshadowed by more technicist models, but also because the general pattern in this largely private and lightly regulated sector is one of rapid market expansion, dilatory policy, and regulatory turbulence, often caused by legislative stalemate. ${ }^{12}$ In the context of the highly controversial recent merger of the IVF and gene-editing platforms, it has become even more essential to appreciate the sociological aspects of "translational" bioscience in order to provide the groundwork for more viable governance.

In contrast to the global pattern, the UK is the single exception that proves the general rule. Its elaborate system of well-established and orderly national governance over "human fertilization and embryology" encompasses not only assisted conception but also human embryo research, cloning, surrogacy, gamete donation and storage, stem cell research, human-animal "cybrids," mitochondrial replacement therapy, and preimplantation genetic diagnosis. How did this unusual system of "reprogovernance" come into being, and what are the secrets of its success? Unlike many countries, which have a rigid legal system but diminishing public support for its underlying ethical principles, such as Germany, or the United States, where legislation is a patchwork of state-level ordinances, the UK has had both comprehensive national legislation and enough public confidence to support successive revisions of the law through primary Acts of Parliament over nearly thirty years. ${ }^{13}$ One reason UK law has been so resilient is that it is not based on an absolute ethical principle (as in Germany), but rather on a loose but generally agreed upon equation between constitutional precedent, public morality, and civic good-a position frequently described as British "pragmatism."14 Indeed, a pragmatic social contract underlies the UK's strict-but-permissive approach to promoting a sciencepositive political (and entrepreneurial) context for controversial bioscientific experimentation, which is that in exchange for allowing such research to

12 Sheila Jasanoff, Designs on Nature: Science and Democracy in Europe and the United States (Princeton University Press, 2005); Spar, Baby Business.

13 Sarah Franklin, "The HFEA in Context," Reproductive Biomedicine Online 26, 4 (2013): $310-12$.

14 For a fuller account of the "pragmatic" British approach, see Mary Warnock, Nature \& Morality: Recollections of a Philosopher in Public Life (Continuum, 2004), 100; Jonathan Robert Montgomery, "Rights, Restraints and Pragmatism: The Human Fertilisation and Embryology Act 1990," Modern Law Review 54, 4 (1991): 524-34. 
continue, it will be subject to the very highest level of regulatory surveillance, directly overseen by Parliament and backed up by statutory penalties for misconduct upheld through criminal law. ${ }^{15}$ At the outset, the centerpiece of this unique means of regulating human reproductive bioengineering was a precise translation of human embryology into a series of "developmental landmarks." This provided the groundwork for the viable and enduring social consensus that has since allowed the continuous extension of human embryonic innovations into a wide range of new sectors. As I will show here, revisiting how this process unfolded helps us to better understand the sociological dimensions of biological translation. ${ }^{16}$

A close reading of newly declassified Department of Health and Social Security (DHSS) files from the UK's famous Warnock Committee of Inquiry into Human Fertilisation and Embryology reveals the means by which its members established the most important "line" on which UK policy came to be based - the famous fourteen-day rule, enacted into law in 1990 - which resulted in research on human embryos being permitted subject to strict regulation. ${ }^{17}$ These documents offer, for the first time, a comprehensive picture of how key decisions were arrived at and the obstacles that had to be overcome to reach the keystone innovation of a fourteen-day limit to embryo research. In turn, it is possible to reconsider both the policy template and the broader social contract this legislation established as "translational," thus expanding the concept of "translational" biology beyond its conventional meaning. This expansion is especially important given that the fertility industry now serves as a model for other bioinnovation sectors. That is, to the extent that the governance of human fertilization and embryology have set the stage for public expectations concerning translational bioinnovation generally-in areas such as stem cell research, regenerative therapeutics, or personalized genomics - it

15 Derek Morgan, Blackstone's Guide to the Human Fertilisation and Embryology Act 1990: Abortion and Embryo Research, the New Law (Blackstone Press, 1991; Emily Jackson, Regulating Reproduction: Law, Technology and Autonomy (Hart Publishing, 2001); Wendy Y. Chang and Alan H. DeCherney, "History of Regulation of Assisted Reproductive Technology (ART) in the USA: A Work in Progress," Human Fertility 6, 2 (2003): 64-70.

16 Jennifer Gunning and Veronica English, Human In Vitro Fertilization: A Case Study in the Regulation of Medical Innovation (Medico Legal Studies) (Dartmouth Publishing, 1994); Duncan Wilson, "Creating the Ethics Industry: Mary Warnock, in Vitro Fertilization and the History of Bioethics in Britain," BioSocieties 6, 2 (2011): 121-41; Duncan Wilson, The Making of British Bioethics (Manchester University Press, 2014); Michael Mulkay, The Embryo Research Debate: Science and the Politics of Reproduction (Cambridge University Press, 1997).

17 Following a ten-year search, an incomplete but comprehensive series of declassified Warnock Committee files was unexpectedly discovered on a research visit in January 2016 to the Department of Health Repository in Burnley, Lancashire. Fifteen of these files (FPS/0015/0001/V02-11, and FPS/0015/004/V01-6) are currently being transferred to the National Archives in Kew. These files cover the period 1 April 82 through 13 July 1984, and are divided roughly into papers prepared for meetings, internal correspondence, and minutes and follow-up from meetings. A previously released, incomplete set of Warnock files is held at the National Archives as part of the Medical Research Council files, in the FD7 series. 
is timely to consider the translational lessons that IVF's surprising history, uniquely, can provide.

\section{FILLING A LEGAL VACUUM}

No one had ever legislated in the novel area of "human fertilization and embryology" when the Oxford philosopher Mary Warnock was appointed in 1982 to chair a committee responding to the birth of the world's first test-tube baby, Louise Brown, in Oldham, Lancashire in 1978. Although the first clinical success of IVF was banner headline news and widely celebrated across the globe, "test-tube babies" were also the object of widespread suspicion and concern. To complicate matters, IVF was not the only technique included in the Warnock Committee's expansive brief "to examine the social, ethical and legal implications of recent and potential developments in the field of human assisted reproduction." 18 Other areas requiring regulation included surrogacy, egg and sperm donation and storage, artificial insemination, sex selection, preimplantation genetic diagnosis, cloning, and embryo research. Because these were matters of "special" moral significance, and considerable legal uncertainty, the Committee would have to consider ethical and philosophical questions alongside legislative, medical, and scientific ones in the effort to devise a viable political strategy through which to implement successful regulation. ${ }^{19}$

Of particular concern to the general public in the wake of the world's first test-tube baby was the specter of secretive scientific experiments aimed at manipulating human embryos, although such anxieties were by definition speculative and often vague. A more concentrated source of opposition to IVF in the late 1970s was the burgeoning Right-to-Life movement, for whose proponents IVF was inherently immoral and part of the same political territory as abortion and contraception. As sociologist Michael Mulkay notes in his analysis of the historic debate surrounding the effort to fill the "legislative vacuum" created by the birth of Louise Brown, the Warnock Committee was appointed at the outset of a major conservative backlash against the reforms of the 1960s, which had gathered pace throughout the 1970s, led by the anti-abortion lobbies LIFE and SPUC (Society for the Protection of Unborn Children). ${ }^{20}$ Campaigns to reassert moral conservatism, and to restore the traditional family as a centerpiece of modern life, had gained popularity as well as political momentum by the early 1970s, well before the elections of Ronald Reagan and Margaret Thatcher returned conservative parties to power on both sides of the Atlantic in 1978 and 1979. As Mulkay notes, "The members of these organizations were determined

18 Report of the Committee of Inquiry into Human Fertilisation and Embryology, Cmnd 9314 (Her Majesty's Stationary Office, 1984); Mary Warnock, A Question of Life: The Warnock Report on Human Fertilisation and Embryology (Basil Blackwell, 1985).

19 Warnock, Nature and Mortality.

20 Mulkay, Embryo Research Debate. 
to restore to British society what they saw as the basic moral principles and the essential forms of conduct of the past.... They were particularly disturbed by the changes in the patterns of family life... They maintained that the present moral decline would be irreversible unless there was a wholesale return to the "traditional nuclear family.", 21

Concerns about moral laxity and family decline were widely shared within the Conservative Party, many of whose members championed a "return to Victorian values." 22 In the United States, abortion clinics became the target of domestic terrorist attacks from the late 1970s onward as the (mostly evangelical Christian) campaign to overturn the permissive reforms of the 1960 s increasingly made the protection of unborn life into its core symbolic cause. ${ }^{23}$ The UK saw a similar concentration on abortion politics from the religious right, through which broader moral concerns about sixties-era reforms, such as the legalization of homosexuality and divorce, could be harnessed to the task of restoring traditional family values in their effort to rescue the nation's future. ${ }^{24}$ The argument that an erosion of family values played a key role in a weakening of the nation's moral economy had strong support among Conservative party members in both Houses of Parliament, where, in the words of the Lord Bishop of Rochester, the introduction of IVF was seen to exacerbate the "acute moral problems" facing society. ${ }^{25}$

Parliamentary calls for an inquiry into the social, legal, and medical implications of IVF similarly referred to its potential to "imperil the dignity of the human race, threaten the welfare of children, and destroy the sanctity of family life." ${ }^{26}$ Conservative moral pressure groups targeted the regulation of assisted conception as an opportunity to overturn the 1967 Abortion Act. Thus it quickly became evident that a key challenge for the so-called "TestTube Baby Committee," perhaps its primary obstacle, would be the difficulty of avoiding the highly polarized abortion debate and its political terrain dominated by anti-progressive moral causes. In the autumn of 1982, when the Warnock Committee began their negotiations, it was unclear whether a majority of either the British public or Parliament supported embryo research or

21 Ibid., 14; and see Sarah Franklin, "UK IVF: A Tale of Two Halves," in Vera Mackie, Nicola Marks, and Sarah Ferber, eds., The Reproductive Industry: Intimate Experiences and Global Processes (Lexington Books, 2019), 15-30.

${ }^{22}$ Fenella Cannell, "Concepts of Parenthood: The Warnock Report, the Gillick Debate, and Modern Myths," American Ethnologist 17, 4 (1990): 667-86.

23 Rosalind Pollack Petchesky, Abortion and Woman's Choice: The State, Sexuality, and Reproductive Freedom (Northeastern University Press, Series in Feminist Theory, 1990 [1984]); Faye D. Ginsburg, Contested Lives: The Abortion Debate in an American Community (University of California Press, 1989).

24 Sarah Franklin, Celia Lury, and Jackie Stacey, "Feminism, Marxism and Thatcherism" in S. Franklin, C. Lury and J. Stacey, eds, Off-Centre: Feminism and Cultural Studies, (Harpercollins Academic, 1991), 21-46.

25 Lord Bishop of Rochester, House of Lord Debates, 9 July 1982, vol. 432, column 1000-1.

26 Lord Campbell, House of Lord Debates, 9 July 1982, vol. 432 column 1000-1. 
IVF. While a vocal minority of hardline religious activists stridently opposed IVF and embryo research, it was much harder to determine how the average British citizen viewed such novel scientific innovations. On the Committee itself, unanimous support for most techniques, including IVF, was not matched with equal willingness to allow research on embryos, particularly those created for research purposes. Together, seven of the sixteen members ultimately dissented on this matter, which proved the most controversial single issue the Committee had to wrestle with throughout its two years of deliberations between 1982 and 1984.

The means by which the Committee debated the science of embryology thus became a central concern of its chair, Warnock, and Dr. Anne McLaren, the most senior scientific member of the Committee and a professional biologist. ${ }^{27}$ Careful examination of the strategies Warnock and McLaren employed to persuade their colleagues, and later Parliament, to back a comprehensive legislative package based on the fourteen-day rule reveals the origins of a unique and unprecedented process of biological translation that would ultimately take nearly a decade to become the basis for new legislation. The fourteen-day rule, which is based on a highly technical translation into law and policy of specific biological "landmarks" in the development of human embryos, has since become the global "benchmark" legislation. ${ }^{28}$ It thus presents a timely opportunity to explore and significantly expand what we understand "biological translation" to mean in sociological, historical, and political terms. ${ }^{29}$

\section{WHERE TO DRAW THE LINE?}

With the release of many of the Warnock Committee documents in January 2016, in a new set of original DHSS files held by the Department of Health Repository in Burnley, Lancashire, we can now examine key moments in the Committee's deliberations, including the background preparations for their meetings, briefings to the Chair, and internal memos assessing the progress of the so-called "In Vitro Inquiry." These all point to the crucial meeting on 9 November 1983, when the Committee grappled with the most politically volatile question at the heart of their Inquiry, concerning embryo research (see image 1 ). ${ }^{30}$

27 McLaren was chosen when Professor Walter Bodmer was unable to accept his invitation to join the Committee.

${ }^{28}$ Kirsty Horsey and Hazel Biggs, eds., Human Fertilisation and Embryology: Reproducing Regulation (Routledge-Cavendish, 2007).

29 More than a dozen countries, including India and China, restrict in vitro research on human embryos to within the first fourteen days of development.

30 The Committee met eighteen times in just less than twenty-one months between October 1982 and June 1984, and as a consequence, preparations were elaborate and thorough but also rushed and fast-paced. The Agenda for 9 November 1983 was revised and recirculated at least once before the meeting, and papers were renumbered and reordered. Briefings from the Secretariat, correspondence to other government departments, and minutes from the meetings fill in some details about what was discussed, what conclusions were drawn, and what evidence proved influential. 


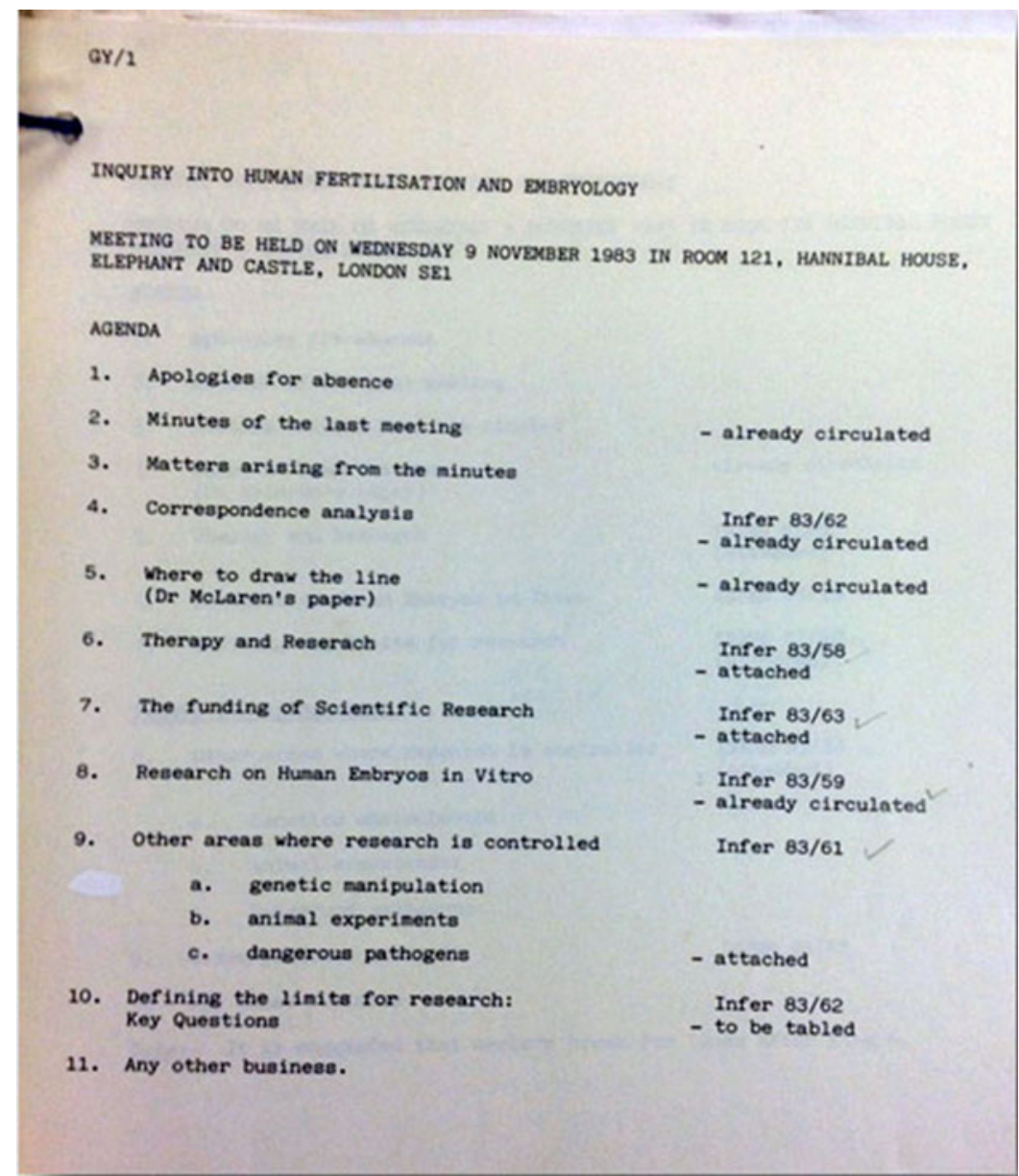

Figure 1. Agenda for the 9 November 1983 Meeting. It leaves out some key papers, mislabels others, and lists them in the wrong order. McLaren's crucial discussion paper, listed here, has never been found.

As we shall see, the most significant feature of that meeting is the way in which a precise biological translation of embryology was used to establish the essential "line" on which to base a proposal for an unusually comprehensive, robust, and permissive means of assisted reproduction. Around the table, several divergent constituencies reached an initially tentative, but ultimately decisive union through which a highly specialized form of biological argumentation could form the basis for an Act of Parliament. This consensus emerged from an elaborate series of steps in a process of reasoning that ultimately turned 
on the question of what distinguishes the earliest stages of embryonic development from what the Committee's final report called "the embryo proper." This crucial but much contested distinction provided the fragile ground of workable consensus both during and after the Inquiry. It exemplifies a form of biological translation that has become increasingly familiar and consequential in debates concerning reproductive biomedicine, stem cell research, cloning, and preimplantation genetic diagnosis (or, more recently, mitochondrial DNA, "cybrids," and CRISPR).

These "settlement" translations, as we might call them, are grounded in well-established biological evidence, but are also provisional, in the sense that different evidence could be used to ground different legislative actions in "basic biological fact." Successful translations of "biological fact" into policy landmarks rely on a dialogic process of iterative settlement through which increasingly formulaic translations of basic biological science are gradually refined to fashion a sufficiently consensual basis for legislation. ${ }^{31} \mathrm{Cru}-$ cially, and as the Warnock case demonstrates so well, successful translations must address not only what diverse constituencies know about specific biological processes, such as the formation of the early human embryo, but also how they feel about them. ${ }^{32}$ It is out of this necessary plurality of descriptions, images, perceptions, and narratives - all of which play different roles in public debate - that a distinctive translational paradox emerges, namely that the "basic biological facts" can never remain strictly biological in social practice. The Warnock Committee had to discipline and orchestrate the hybridity of debate over controversial bioinnovations into viable public policy by mustering expert facts, moral boundaries, individual feelings, persuasive narratives, convincing images, and reassuring logics. The way they accomplished this, and the

31 José Van Dyck, Manufacturing Babies and Public Consent: Debating the New Reproductive Technologies (Palgrave Macmillan, 1994); Patricia Spallone, "Reproductive Technology and the State," in Patricia Spallone and Deborah Lynn Steinberg, eds., Made to Order: Myth of Reproductive and Genetic Progress (Pergamon Press, 1987), 166-83; Jeanette Edwards et al., Technologies of Procreation: Kinship in the Age of Assisted Conception (Manchester University Press, 1999); Marilyn Strathern, Reproducing the Future: Anthropology, Kinship, and the New Reproductive Technologies (Manchester University Press, 1992); Marilyn Strathern, After Nature: English Kinship in the Late Twentieth Century (Cambridge University Press, 1992); Sarah Franklin, Embodied Progress: A Cultural Account of Assisted Conception (Routledge, 1997); Sheila Jasanoff, "Making the Facts of Life," in Shela Jasanoff, ed., Reframing Rights: Bioconstitutionalism in the Genetic Age (MIT Press, 2011), 59-84; Wilson, "Where to Draw the Line?," ch. 4 in Making of British Bioethics.

${ }^{32}$ For a discussion of the affective complexity of biological facts, see Sarah Franklin "From Blood to Genes? Rethinking Consanguinity in the Context of Geneticization," in Christopher H. Johnson et al., eds., Blood and Kinship: Matter for Metaphor from Ancient Rome to the Present (Berghahn Books, 2013), 285-320. See also works in the new kinship studies: e.g., Sarah Franklin and Susan McKinnon, eds., Relative Values: Reconfiguring Kinship Studies (Duke University Press, 2001); Janet Carsten, ed., 2000, Cultures of Relatedness: New Approaches to the Study of Kinship (Cambridge University Press, 2000); and especially Janet Carsten, Blood Work: Life and Laboratories in Penang (Duke University Press, 2019). 
criticisms and challenges they faced along the way (and faced afterwards), remain instructive because they help us better understand biological translation in social and affective terms, as well as scientific and legislative ones. ${ }^{33}$

9 NOVEMBER 1983

All but one of the sixteen members of the Warnock Committee attended their twelfth monthly meeting in Hannibal House, the iconic London headquarters of the former DHSS based in Elephant and Castle. At this meeting, one of the most important in the Inquiry's brief, two-year life, the entire day was spent discussing one issue: whether to permit any experimentation on human embryos, and if so, under what conditions. A briefing note ${ }^{34}$ to Mary Warnock from Committee Secretary Jenny Croft summarized the "Organisation of the Day's Business" and anticipated possible outcomes: "As agreed at the last meeting [13 October 1983], the whole of Wednesday is to be devoted to a discussion of experiments on embryos.... We had thought in terms of allowing the morning for the more general discussion, and turning to the matters requiring decisions after lunch." She continued:

It may be that we cannot get answers to all the questions at the meeting, but I think we agreed we might need more than one meeting on the subject [since] it is a topic where it is important that the inquiry feel satisfied with the position they eventually take. If it would be helpful, we could draw together the lines of discussion on Wednesday, and any decisions which are reached into a connected piece of narrative for the next [December] meeting, so that members could consider whether this indeed represents their views. $^{35}$

Four papers $(57,59,62$, and McLaren's paper) were pre-circulated with the minutes of the October meeting, and three $(58,61$, and 63$)$ were attached to the "revised agenda" for the November meeting circulated on 4 November with instructions from the secretary in a hand-written note that "most of the papers are factual" and would be taken before lunch in order to allow a discussion "in general terms" before turning to the "key issues" of how to limit research, for which a final paper (64) was tabled at the meeting. ${ }^{36}$ For Agenda Item 4, the first major item for discussion, a single-page document entitled "Correspondence Analysis" summarized the letters Committee had received to date (image 2 ).

In a neat numeric table, Paper 62 presented a sobering set of sums. Against only eight letters written in support of IVF, 123 correspondents opposed either

\footnotetext{
33 Trisha Greenhalgh and Sietse Wieringa, "Is It Time to Drop the 'Knowledge Translation' Metaphor?" Journal of the Royal Society of Medicine 104 (2011): 501-9.

34 Jenny Croft, “Organisation of the Day's Business," Nov. 1983, file FPS 15/4, vol. 4, "Inquiry into Human Fertilisation: Papers for Meetings," Department of Health Repository, Burnley, Lancashire.

35 Ibid.

36 Ibid.
} 


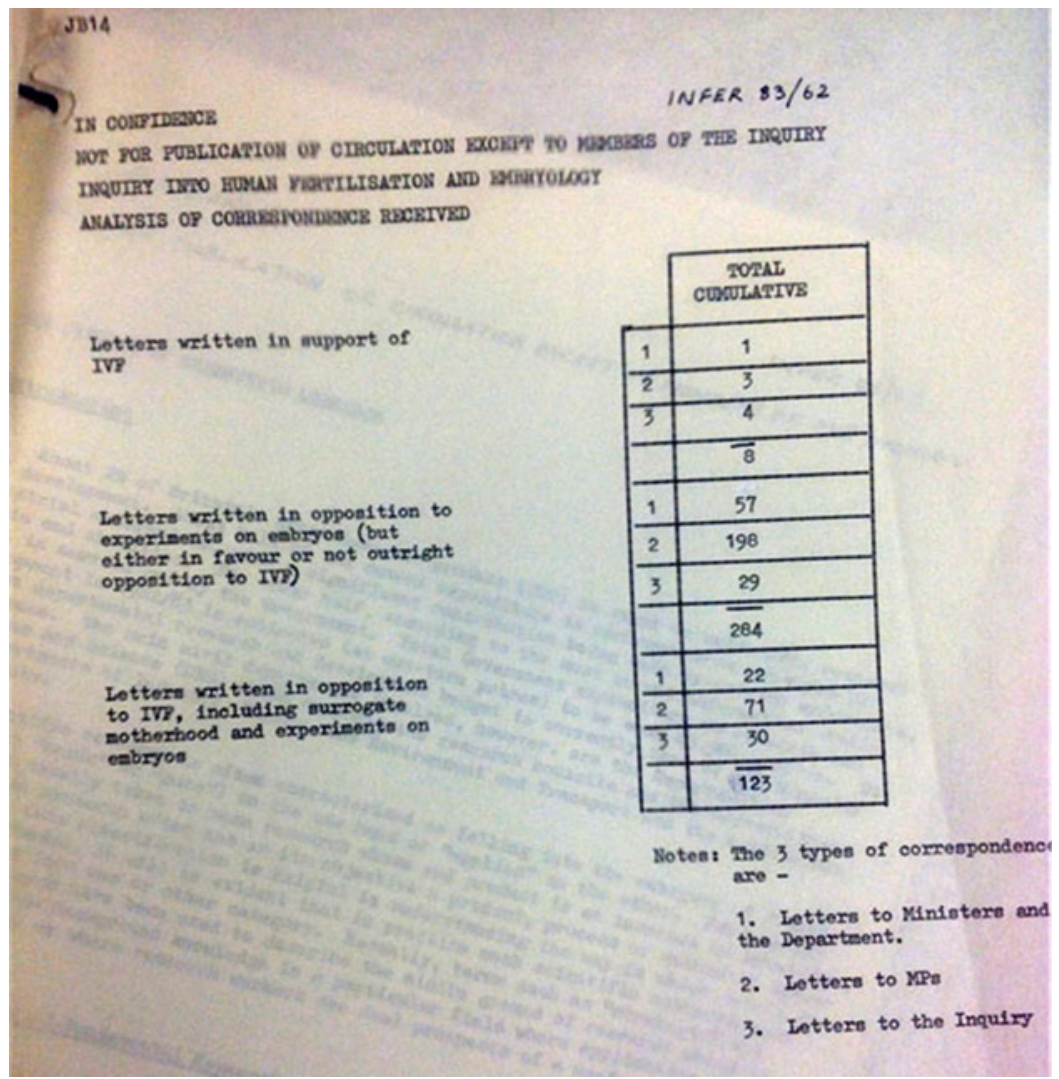

Figure 2. "Analysis of Correspondence Received." This first item for discussion at the 9 November 1983 meeting shows the overwhelming opposition, particularly to embryo research, expressed in letters to the Warnock Committee.

IVF or surrogacy, while another 284 specifically objected to experiments on embryos. Letters written in opposition to IVF, surrogacy, and embryo experiments outnumbered those in favor of IVF by a ratio of over fifty to one.

In retrospect, it is difficult to imagine a more unlikely document to have set the stage for a meeting that would lay the groundwork for the most comprehensive and permissive legislation supporting reproductive biomedicine and embryo research ever enacted. As a starting point for discussion of their most challenging topic to date, about which, as Warnock later wrote, there was "bound to be criticism that we have gone too far, or not far enough,"37

37 Warnock, Question of Life, vii. 
such a large "no vote" must have felt like a shot across the bows. Given that only a small minority of members were inclined to support a ban on IVF and embryo research, did the placement of this document at the top of the agenda signal a call to action, or even a red flag? In the breakdown by source of correspondence, three categories are identified: (1) "Letters to [Cabinet] Ministers and the Department" (the DHSS); (2) "Letters to MPs"; and (3) "Letters to the Inquiry." By far the largest single number, 198-more than twice the total in any other category-were letters opposing embryo research.

Faced with these daunting figures, members then turned to the task at hand of how to define specific limits for regulating embryo research. Papers 58 (“Therapy and Research"), 61 ("Other Areas Where Research Is Controlled"), and 63 ("The Funding of Scientific Research") contain factual background information to guide discussion. "Therapy and Research" is intended to help distinguish between the types of embryos created for different kinds of research ("experimental," "therapeutic," and "pure"), and thus to aid in determining whether the limits on embryo research should be the same for all of them. Paper 61 outlines the control mechanisms used in other areas of controversial scientific research, including genetic manipulation, animal experiments, and dangerous pathogens. Paper 63 explains how funders decide what kinds of research should and should not be supported. ${ }^{38}$ All three address problems laid out in the primary framing document on embryo research, Paper 57, "Experiments on Embryos: Key Questions," which sets out the specific, agreed, and technical parameters for the Inquiry's discussion of human embryo research in its core section, paragraph 6 . That paragraph outlines the questions the Committee should try to answer in an eleven-point list. They range from whether the creation of embryos for research should be allowed at all, to what limits should be imposed on it, who should determine which experiments are permissible, whose consent would be needed, and whether a "cut-off" point should be set at five-six days (when implantation begins), eleven-twelve days (when it ends), or fourteen days? The list concludes with questions about a regulator: "Should there be a nationally recognized system of controls or a nationally recognised Code of Practice? A number of submissions have for example suggested the creation of a new statutory body to license research in this field." 39

Paper 57 not only summarizes the problems the Committee will need to solve and the options for doing so, but also acts as a reminder from the

\footnotetext{
38 A proposal to fund IVF and human embryo research from Robert Edwards and Patrick Steptoe, submitted to the Medical Research Council in 1971, was not funded since the research was considered ethically uncertain. Martin H. Johnson et al., "Why the Medical Research Council Refused Robert Edwards and Patrick Steptoe Support for Research on Human Conception in 1971," Human Reproduction 25 (2010): 2157-74.

39 Paper 57, "Experiments on Embryos: Key Questions."
} 
Chair and the Secretariat of what has already been agreed to. For example, it notes: "Members agreed at the first meeting [that] for the practical purposes of the Inquiry the embryonic stage of development would be taken to cover the period from fertilization until the end of the eighth week of gestation." As far as the "central issue" is concerned, it continues, "the question is not, as members have said on a number of occasions, when does life begin, which the Inquiry has agreed is a matter of belief as much as science," but instead, "what moral status should be afforded an embryo, and hence what degree of protection, if any, should it be given." 40 Paragraph 6 foregrounds practical requirements: when will the cut-off point be; who will enforce it; is primary legislation required; are different rules needed for different kinds of embryos, or different uses of embryos? The paragraph also highlights questions of judgement, such as whether the scientific community should be allowed to self-regulate, how the public view will be represented, and whether there should there be a new statutory body or "special organization." But Paper 57 is also noticeable for what it leaves out: there is no mention, for example, of "the status of the human embryo." The words "ethical" or "moral" are absent, being replaced by potential actions: it asks whether various kinds of research should be "possible," "allowed," "permissible," or "acceptable," and if so, under what form of governance.

In its summary of the "main strands of opinion" concerning experiments on embryos, Paper 57 describes two opposing sides: one that seeks to ban embryo research entirely and another that is "essentially utilitarian and pragmatic" and stresses the benefits such research could bring. Key to the pragmatic approach, the Paper points out, is the recognition that "if such research is to be accepted by the general public, it must be performed within certain clearly defined limits," or what it calls a "cut-off point": "Although supporters of this approach often suggest a cut-off point after which no experiments should be permitted, these points tend to derive from practicalities such as the length of time an embryo can, in the present state of knowledge, be sustained in vitro, rather than on any view as to a qualitative difference in the embryo before and after the chosen point." 41

Emphasizing the difficulty "in the present state of knowledge" of selecting a "chosen point," Paper 57 closes with a cautious gesture toward the afterlife of any particular "view" on this matter by noting the "somewhat arbitrary nature of these cut-off points, since the rationale for their existence could be overturned by a breakthrough in technology." In this way, the path forward is clearly marked for the largely pro-research Committee members, while they

40 Many issues discussed in Paper 57 were agreed upon at the Inquiry's second meeting, in November 1982, at which both Anne McLaren and the MRC gave presentations on IVF and embryo research (Warnock, Nature \& Morality).

41 "Experiments on Embryos," 2-3. 
are forewarned that a neat, self-evident, and inherently biological end point, or line, is unlikely to be provided by any "practicalities," since the very technologies in question will likely override any such limit in due course (as, indeed, they recently have).

\section{PAPER 59}

A fifth briefing document, Paper 59, "Research on Human Embryos In Vitro," was prepared by the Secretariat just prior to the 9 November meeting to further assist the Committee in determining what limits should be set on embryo research. This paper is concerned with not only the "cut-off points" in time, or "age," of the embryo, or the types of embryo in question (according to their provenance and intended uses), but also the categories of research to which they belong and the "purposes and objectives" for which they are designed and permitted. ${ }^{42}$ Research on in vitro-fertilized embryos ranges widely, Paper 59 explains, covering many types of situations and species. At one end of the spectrum are simple observations and descriptions of the stages of embryonic development in "fish, amphibians, reptiles, birds and mammals" which "are basically the same" but differ slightly from man. ${ }^{43}$ This form of comparative study requires no experimental modification of the embryo. Indeed, the document notes, the "simple observation of human embryos growing in vitro is claimed by some not to be research at all."44 The second category, "therapeutic" research, includes experiments designed either to enhance embryonic growth or improve clinical practice, and thus increase the success rate of IVF. Paper 59 goes on to describe various possibilities of combining IVF with genetic analysis. This is followed by a section explaining the use of vitro-fertilized human embryos, or cells from these embryos, to test for the toxic effects of chemicals or drugs. Closing sections anticipate "long-term proposals" such as stem cell research, the in vitro growth of replacement organs (regenerative medicine), transspecies fertilization (cybrids), cloning, and ectogenesis. ${ }^{45}$

This typically summative, but directive, paper from the busy Secretariat thus combined a far-reaching "horizon-scanning" view of the current and future uses of research on in vitro fertilized human embryos with some important clarifications related to paragraph 6 of Paper 57, which had both subtle and explicit implications for the issues the Committee had to address. For example, although much experimental testing could be done on other species it emphasized, "In the end proof that the methods work can only be established through

${ }^{42}$ Paper 59, "Research on Human Embryos In Vitro," Department of Health, Burnley file FPS $15 / 3$, vol. 3 , p. 7 .

43 Ibid., 1.

44 Ibid., 1.

45 Ibid., 7. 
work involving human IVF embryos." ${ }^{46}$ Similarly, research could be undertaken using cells that were "not destined to become part of the embryo proper," but ultimately "the time would come" when human embryos would need to be used in experiments to determine if such methods were "possible and reliable." ${ }^{\prime 47}$ Consequently, although seemingly separate, the categories of therapy and research, and of experimentation vs. treatment, overlapped and fed into each other. The paper concluded, "Members will no doubt wish to discuss the extent to which any of these purposes or objectives are sufficient to justify the continued research use of IVF embryos." 48

Paper 59 contains a two-page annex that combines a short technical description of "The Stages of Post Fertilisation Development" with a handdrawn diagram of these stages to assist Committee members in their discussions. Taken together with the emphasis on the need for the Committee to determine a specific cut-off point for embryo research in terms of what Paper 57 refers to as "a qualitative difference in the embryo before and after the chosen point," the road map in "Annex A" would have been central to establishing the basic biological blueprint guiding any decisions. Paper 59 is, in essence, a further development of Paper 57, and a pointed response to the challenge to make the decision about a "cut-off point" appear less "arbitrary." In just two pages, the annex provides a technically advanced and precisely signposted post-fertilization narrative. This is accompanied by a twelve-stage visual diagram that unmistakably prioritizes one very specific point in the developmental process, when the embryonic disc forms beneath the amniotic cavity during the process of implantation. Annex A is introduced on the first page of Paper 59 where it is noted, "Details of post fertilisation development are summarised in very simplified form in Annex A" (see image 3). ${ }^{49}$

The summary begins simply enough but quickly becomes more technical: "At fertilization the egg and sperm unite to become one toti potential cell with a single nucleus that contains the chromosomes derived from both parents. This single cell (or 'Fertilized egg') then begins to divide rapidly into two, four, eight, sixteen cells, and so on. At this stage the cells hang together in a configuration similar to that of a blackberry. This is technically called a Morula."50 Since it was unlikely that any Committee members would know the meaning of "toti potential," 51 its significance to development is clarified in subsequent

46 Ibid., 2.

47 Ibid., 3.

48 Ibid., 7.

49 Ibid., 8 .

50 Ibid., 8 .

51 The term "toti potential capacity" would have been well established within the specialist community of developmental biologists, but rarely used outside of it. Now more commonly referred to as "totipotency," this capacity has become more familiar to wider audiences in the context of debates over stem cell research. 


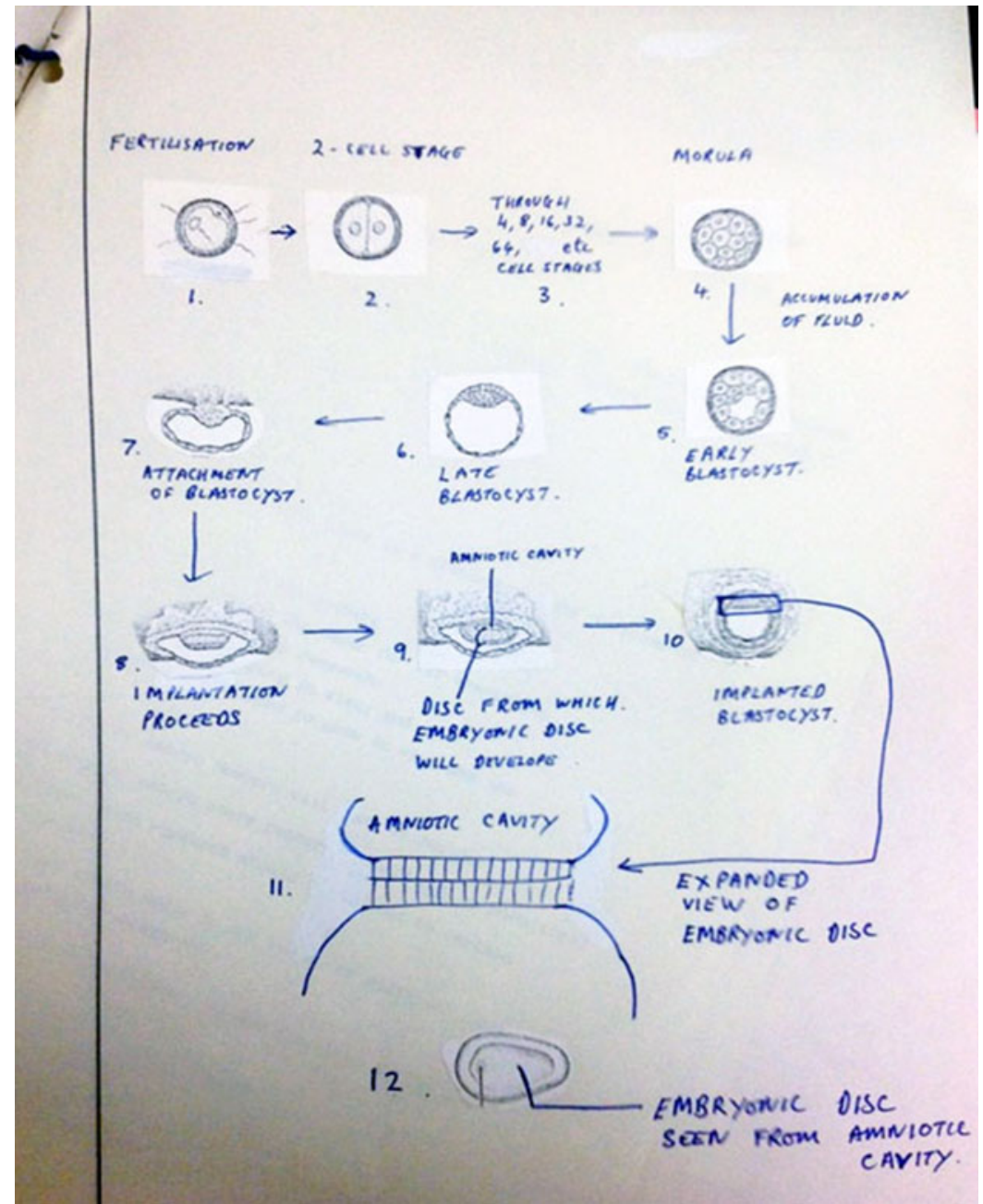

FiguRE 3. "The Stages of Post Fertilisation Development." This linear illustration of the twelve earliest stages of embryonic development in vitro appears in Annex A of Paper 59, "Research on Human Embryos In Vitro," prepared by the Secretariat for the 9 November 1983 meeting concerning "where a line should be drawn" to limit research. Of unclear origin from within the Secretariat, this diagram appears to contain pasted cutouts from a photocopy of a textbook illustration.

paragraphs that explain the transition from morula to blastocyst stages, by which time "the cells have lost their toti potential capacity," except for a portion called the inner cell mass, "from which the embryo will be formed." The rest of the blastocyst, "although derived from the original fertilized egg and having the same genetic and chromosomal make-up," will not contribute 
cells "to the embryo, fetus or child." The one-page "simplified" summary of "The Stages of Post Fertilisation Development" accompanying the diagram in Annex A of Paper 59 is thus notable in its combined narration of the embryo in toto (from fertilized egg to morula to blastocyst) followed by its description and visual illustration of the emergence of "the very small number of cells" that make up the inner cell mass, "which continues to divide until an area within it can be identified as the "embryonic plate." 52 The description concludes: "Thus, it will be seen that the embryo (fetus and child) actually develop from a very small number of cells, all contained within the embryonic plate. The majority of cells of the pre-implantation embryo contribute to the formation of the

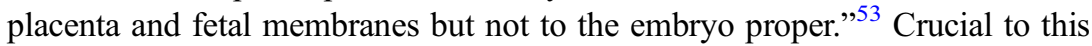
condensed account of post-fertilization development is thus a division of the "embryo" into two distinct entities: the "pre-implantation embryo" (the whole embryo) and the "embryo-proper" (the part of the inner cell mass that becomes the fetus and child).

This same division is clearly illustrated in the accompanying twelve-stage diagram that proceeds from fertilization (1) through the two-cell stage (2); 4-64-cell stages (3); morula (4); early blastocyst (5); late blastocyst (6); attachment of blastocyst (to uterine wall, 7); implantation (8); and formation of the "disc from which embryonic disc will develop" (9). Illustrations 10, 11, and 12 all depict the same stage - the formation of the embryonic disc-from different angles and in different scales.

The emphasis the diagram places on the embryonic disc is prominent and distinctive, and also conclusive, in that it concludes with an "expanded view" of the division between the two sections of the developing embryo on about day eleven, which is drawn as a single line. Whereas stages 1 through 8 are simply labeled and numbered, 9 through 12 represent one single stage in greater visual and textual detail: the formation of the embryonic disc, which is initially illustrated in situ within the implanted blastocyst (9-10), then at a larger scale (11), and finally from below (12). That the diagram culminates in an enlarged, multidimensional view of the embryonic disc's formation further underscores the sense of a key and clearly visible transition between one phase of development and another.

With the culminating emphasis of this Annex A diagram in mind, we can interpret the claim in Paper 59 that "the majority of the cells in the preimplantation embryo contribute to the formation of the placenta and fetal membranes but not to the embryo proper" 54 even more pointedly, for it emerges that Papers 57 and 59 are concerned with not only key questions but also key divisions. Moreover, it is possible to read Annex A as roadmap signposting the key

\footnotetext{
52 Paper 59, "Research on Human Embryos In Vitro," 8.

53 Ibid., 8 .

54 Ibid.
} 
developmental landmarks that could justify qualitative rather than practical cut-off points. In effect, and among other things, Paper 59 provides a neatly divided developmental narrative, which is reinforced both textually and diagrammatically in Annex A by an emphasis on key transitions. An overarching chronology of "the embryo" includes the morula, blastocyst, and postimplantation blastocyst stages familiar to the Committee since their first meeting, at which, "Members agreed [that] the embryonic stage of development would be taken to cover the period from fertilization until the end of the eighth week of gestation." But a second, more specialized meaning of "embryo" introduced in Papers 57 and 59 focuses on specific parts of embryos. This second definition becomes increasingly restrictive, including fewer and fewer cells as development progresses, marked by a series of divisions between different types of cells within the original fertilized egg. In the second paragraph of Annex A, "embryo" initially means "complete embryo," as in "each toti potential cell might itself become a complete embryo." This definition changes in paragraph 3: "When the blastocyst forms it becomes clear which sections ... include those cells from which the embryo will be formed." This narrower definition is retained in paragraph 4, which explains that "the rest of the blastocyst ... will not contribute cells to the embryo, fetus or child." The meaning of "embryo" is narrowed still further in the final paragraph, in which the embryonic plate (or disc) becomes crucial because "it is this part alone that contains the cells from which the embryo develops." This point is immediately repeated: "Thus it will be seen that the embryo (fetus and child) actually develop from a very small number of cells, all contained within the embryonic plate." ${ }^{256}$ In a third iteration, the point is reinforced by introducing two new and important terms, the "preimplantation embryo" and the "embryo proper": "The majority of the cells in the pre-implantation embryo contribute to the formation of the placenta and fetal membranes, but not to the embryo proper." 57

“THE EMBRYO PROPER"

To understand the coming into being of the "embryo proper" it is helpful to retrace its emergence across the key papers leading up to the crucial November

55 Ibid.

56 The question of who prepared Annex A is complicated by divergences of its terminology ("disc" versus "plate"), the hybrid nature of its composition (cut-out images from a textbook), and its seemingly hurried composition (using ball point pen and white-out correction fluid). It is probably based on McLaren's missing discussion paper but drawn by someone else (the handwriting is not McLaren's). When I contacted Metters about the diagram in 2016, he could not recall its source.

57 Paper 59, Annex A, p. 8. Stage 12 in the diagram is not labeled "the embryo proper," but that is the name the embryonic plate, or disc, has implicitly acquired, and it appears in the crucial section of the Warnock Report written by McLaren, "Early Human Development," in the chapter "Scientific Issues" (Warnock, Question of Life). 
meeting. They all emphasize, in both explicit and more subtle terms, the distinction introduced in the first paragraph of Paper 59 between "research that might make use of human tissue which, though part of the embryonic sac, was not destined to become part of the embryo proper." On page 3 of the same document, this distinction is again emphasized in reference to research on "cells taken from those parts of the blastocyst that will not become part of the embryo proper." 58 The question of what kinds of research can be undertaken on which types of in vitro-fertilized embryos is thus recast as one of which parts of these same embryos have a different qualitative status. Therefore, qualitative criteria can take precedence over "practicalities."

After all, the issue for those attending the 9 November meeting was not the matter of research on embryos in general, but rather what kinds of research should be permitted on which types of embryos, and it is in a curious sentence in Paper 57 that this new ground for classifying embryos is initially named. The transformative, parenthetical sentence introduces a new distinction within the opening section of Paper 57 entitled 'The Meaning of 'Embryo' in this Context": "(Strictly speaking fertilization results in a zygote which goes through morula and blastocyst stages, before the embryo proper can be identified as a discrete group of cells, but in considering the research issues this pre-embryonic period is very important as it is at this stage that in vitro development takes place)."

This sentence not only introduces for the first time in the Warnock papers the concept of "the embryo proper" to describe a "discrete group of cells," but simultaneously inserts the equally transformative and crucial reference to a "pre-embryonic period." Intriguingly, this crucial sentence on the first page of a pivotal paper prepared for a critical meeting seems hastily written: the fifty-two-word insertion is poorly constructed, with a confusing reference to "in vitro development" (possibly a typographical error, since the likely intention was to refer to "individual" development). The first sentence mentioning the "embryo proper" thus appears to have been hurriedly inserted in order to revise a previously agreed upon definition of "embryo" (as the first eight weeks of gestation) by first dividing early embryonic development into different stages (morula and blastocyst), and then replacing "embryo" with the more specialized term "zygote." The turn to more technical language ("strictly speaking"), as well as the use of brackets, suggests the introduction of a post facto technical supplement to the broader definition of "embryo" agreed upon at the Inquiry's outset (for "practical purposes"). The second half of the sentence introduces an additional distinction between the embryo and "the embryo proper," which is described as "very important" in relation to the "key questions" about embryo experimentation that will form the subject of the

$\begin{array}{ll}58 & \text { Paper 59, } 3 . \\ 59 & \text { Paper 57, } 1 .\end{array}$ 
November meeting. The import of this new stage of embryonic development (should anyone remain in doubt) is accentuated by referencing a new timeline for the very earliest stages of human development, which now include the "preembryonic period."

Since Paper 57 was circulated in advance of 13 October 1983 meeting, it confirms that an emergent form of biological reasoning based on the concept of "the embryo proper" was already in use by the Secretariat prior to the November meeting. The October meeting's minutes show that despite an intention to devote the afternoon's discussion to embryo experimentation, all of the time was taken up with discussions of sex selection, and the revised chapter on surrogacy (the first four and a half pages of the minutes, the first eighteen sections, refer in detail to these topics). Only at the very end is brief reference, in item 19, made to Paper 57, confirming that it would not be discussed until November.

\section{EXPERIMENTS ON EMBRYOS}

19. Members considered what papers they would like to see on the subject, at their next meeting. These should include the paper by Dr McLaren which had been tabled; a paper which dealt with the distinction between experiments which were beneficial to the subject of the experiment and experiments with a potential wider benefit; a paper on, or the ability to talk to a scientist, about factors, including non-scientific factors, which lay behind the explicit reasons given for undertaking scientific research. Papers were also being prepared dealing with controls on animal experiments, controls on genetic manipulation research, and controls on the use of dangerous pathogens. ${ }^{60}$

Item 19 refers to the (missing) "paper by Dr McLaren which had been tabled" and describes the three other papers discussed above ("Therapy and Research," "The Funding of Scientific Research," and "Other Areas Where Research Is Controlled"). ${ }^{61}$ However, since it has no paper number and appears on none of the lists of papers for any prior meetings or in the minutes describing them, it seems likely that Dr McLaren's paper was brought to the October meeting, where it would have been distributed in advance of Paper $59 .{ }^{62}$ In her internal memo to Jeremy Metters and two other Secretariat members (Miss Edwards and Mrs. Firth) reviewing the October meeting, Jenny Croft writes that it was "largely devoted to surrogacy though it also considered sex selection" and that "at the end of the meeting there was a very brief discussion of experiments on embryos." She continued:

60 Minutes of the eleventh meeting, on 13 Oct. 1983, p. 5.

61 Although McLaren's paper "Where to Draw the Line?" is recorded as having been tabled in the October meeting minutes, the List of Papers for that meeting does not mention it, and it may have been tabled earlier in the Inquiry (the use of the past perfect progressive tense in the minutes makes the timing of this unclear, and, again, it is curious that no copy has been found among the Warnock files or other archives).

62 Reference is also made to "a discussion paper by Dr McLaren" prepared for the 9 November 1983 meeting, in a confidential note from J. E. Box dated 25 Oct. 1983 (file D 409/191, found in the TNA MRC FD7 series). 
It seems likely that this will prove to be a contentious area, as one or two members are opposed to the concept of experimentation on human material. Mrs Warnock confided to the Secretariat that she personally can find no objection to experiments on embryos at any stage, but I think she recognises that the strength of public feeling requires that there should be some system of controls and that there should probably be some cut-off point after which no forms of experimentation are allowed. What that cut-off point should be is likely to prove the most contentious issue for debate at the next meeting. ${ }^{63}$

If McLaren's paper was indeed tabled at the October meeting and subsequently informed the November meeting's discussion of what controls and limits should be placed on embryo research (if it were to be allowed at all, which by then seemed likely and was clearly the course of action favored by the chair), then one possible function of her "discussion paper" would have been to lay the foundation for the crucial distinctions mapped out in Annex A.

\section{THE MISSING MCLAREN PAPER}

Dr. McLaren's "Where to Draw the Line?" discussion paper is mentioned several times in the surviving documents related to the Warnock Committee, and McLaren published an article with this title in 1984 that contains a very similar argument to that outlined in Annex A and was clearly based on her Warnock role. ${ }^{64}$ This important but missing document outlining the key "developmental landmarks" that might be used to reach a decision about a cut-off point remains a tantalizing archival mystery. ${ }^{65}$ It is not mentioned in the November meeting minutes, nor was it ever given a paper number. Nonetheless, it is highly probable that McLaren's precise and technically advanced translation of developmental biology was the basis for not only Annex A but the entire Warnock strategy. ${ }^{66}$

References in the Warnock files to the document confirm that it covered the same ground as Annex A. For example, in the notes from the Secretariat

63 "Warnock Inquiry: October Meeting," memo from Jenny Croft, 17 Oct. 1983.

64 In her publication "Where to Draw the Line?" (Journal of the Royal Institution of Great Britain 56 (1984): 101-21), McLaren distinguishes between the "early embryo," for which "the term preembryo is sometimes used," and the "definitive embryo," which emerges after two to three weeks (106, her emphasis). Using these terms, she argues, we can indeed identify the "uniqueness" that results from "new genetic material" which establishes "individuality" (ibid., 107). Only after fertilization is "a genetic constitution of one or more adult human beings" established, thus comprising an "important landmark," but the "definitive embryo" does not begin to develop until the embryonic plate is formed in the post-implantation embryo (ibid.). For further discussion of this argument's role in the Warnock Committee, see Wilson, Making of British Bioethics, esp. ch. 4.

65 Interviewed in November 2016 about the missing McLaren paper and the diagram in Annex A, Metters could not recall who had prepared that document. A May 2018 interview with Warnock confirmed her longstanding view that McLaren's main contribution to defining the stages of postfertilization development came in a detailed and memorable presentation to the Committee a year earlier, at their second meeting, in November 1982. The detailed minutes of that meeting make no reference to this presentation, perhaps because they generally do not record contributions by individual members. See Warnock, Nature \& Morality, 93-97.

66 Wilson, Making of British Bioethics. 
prepared over the summer of 1983, mapping out the next six months, we find the following: "November: the use of human embryos for research purposes. There would need to be a number of different papers on the subject. We might for example ask Dr McLaren to provide a short paper describing the various stages of early embryonic development - when does implantation begin, when does neural development start, etc., and what can be learnt at each stage." ${ }^{, 67}$

The minutes of the October meeting refer to "the paper by Dr McLaren, which had been tabled," suggesting it was distributed at that meeting or possibly earlier. A more detailed account of preparations for the November meeting, in the form of the Chairman's Brief that Jenny Croft prepared in the first week of that month, notes, "The paper on key questions caused us some difficulty. Most of the substance on defining the limit is in fact incorporated into Dr McLaren's paper, and there seems to be very little we could add. We also felt that it would be wrong for us as secretariat to attempt to steer the Inquiry in any way on such a central issue. Thus the paper deliberately does not propose a line, but merely sets the questions which will need decisions from the Inquiry."68 The "paper on key questions" referred to here is Paper 60, "Defining the Limits for Research: Key Questions," a two-page summary of Papers 57 and 59 that observes, "Dr McLaren's paper described all the landmarks which have been canvassed as the point after which experiments should not be permitted." 69

\section{DEVELOPMENTAL LANDMARKS}

A confidential internal memo from Jenny Croft to other members of the Secretariat, dated 11 November, gave a very positive summary of the November meeting:

Yesterday's meeting of the Warnock Inquiry proved to be extremely successful. Certainly it was the most constructive meeting we have had. This was all the more surprising given the subject-matter, research on human embryos, where we had expected considerable difficulty and sharp diversions of view. To date this has not surfaced, though I am sure there are differences of position between members. The quality of debate was unusually high, with an evenness of contribution from members which we have not previously seen and with all bar one making a contribution. The tone was uniformly constructive, with a marked desire to be comprehensive and not evade the issues. Progress was slow but rather more certain than on previous occasions. ${ }^{70}$

That same day Croft sent a letter to Miss Martha Woolridge at the Home Office describing the meeting's outcome. It confirms that "members have very much in mind some system of licencing $[$ sic] for experiments on human embryos

\footnotetext{
67 “Preparations for Meetings," FPS 15/3 Department of Health, Burnley.

68 Jenny Croft, “Chairman's Brief,” Nov. 1983.

69 "Defining the Limits for Research," FPS 14/4, vol. 4, Department of Health, Burnley.

70 Croft internal memo, "Warnock Inquiry: November Meeting," 11 Nov. 1983, her emphasis.
} 
which would be parallel to the proposals for animal experiments." She adds that although the Committee "did not reach the point of decision on the 'cut-off' point beyond which experiments on embryos would be band [sic]... I think [it] is likely to be much earlier than the 20 days suggested by your Chief Inspector." $" 11$

From these descriptions of the meeting it appears that a basis for a "cut-off point" was tentatively reached, but not an actual time limit or definite "line." Fulfilling Jenny Croft's cautious expectations about the November meeting, that, "It may be that we cannot get answers to all the questions at the meeting" but that "we could draw together the lines of discussion on Wednesday, and any decisions which are reached into a connected piece of narrative for the next meeting," a clear line of biological reasoning seems to have been established on which a rationale for viable legal limits and a system of licensing could be based.

Paper 60, "Defining the Limits for Research: Key Questions," was revised and distributed for the December meeting as Paper 64. "At the November meeting of the Inquiry," it begins, "members agreed to tackle the issues relating to research on human embryos in the following order: a) by type of embryo; b) by age of embryo; c) by category of research." Like the earlier papers, "Defining the Limits" offers a didactic summary, reminding the Committee members that at their previous meeting the most important "developmental landmarks" had been identified, and that the result had been decisive: "At the end of the meeting members had reached a view on whether research could be carried out on all but one type of embryo, those specially created for research purposes." 72

Minutes from the December 1983 meeting similarly confirm that a clear set of landmarks were established at the November meeting as the basis for the Committee's recommendations, following almost exactly the path laid down in Annex A:

Some members suggested a cut-off point of 14 days after fertilisation which they felt was widely regarded as a reasonable limit by the scientific community. At this date an in vivo embryo would have completed the implantation process. The 14-day embryo would have reached the point in development where the primitive streak had just begun to form at one end of the embryonic disk. Members decided that the limit for research should be 14 days. They decided that the formulation of the limit should be in the following terms: "Not beyond the completion of the implantation stage or 14 days post fertilisation" and that it should also include a reference to the primitive streak. ${ }^{73}$

Despite its odd, polyglot composition, Annex A bears all the signs of being the product of a highly trained biologist with exactly McLaren's expertise. Her

${ }^{71}$ Croft letter to Woolridge, 11 Nov. 1983.

${ }^{72}$ Paper 64, 1-2.

73 Minutes of the "Thirteenth Meeting of the Inquiry into Human Fertilisation and Embryology," 8 Dec. 1983. 
ability to translate a specific developmental landmark - the point at which "the primitive steak had begun to form at one end of the embryonic disc"-into the basis for viable and workable legislation was the result of both a cumulative and collective process. In print, Mary Warnock has frequently praised McLaren's vital role on the Committee, and her superb communication skills, exemplified by her "excellent diagrams" and the "non-intimidating manner which made the science available ... to the wider public." ${ }^{74}$ She is equally effusive in her praise of Anne's "genius as a teacher" and recalls with admiration her "spellbinding powers of exposition and explanation," 75 which she and many others relied upon extensively both during and after the Inquiry, as the Committee's recommendations passed gradually, but steadily and with minimal modification, into law. Clearly, McLaren was a skilled translator of biology, whose "impeccable clarity," "infinite patience," and "unruffled amiability" enabled "the developmental story of the fertilisation and post-fertilisation development of the embryo" to become the basis for the famous fourteen-day rule that has been described as the secret of Warnock's success.

When Martin Johnson and I interviewed Warnock in 2008, she described McLaren's translational role further in terms of providing a "rationale" for "a regulatory line" through which the "crucial issue" for the Inquiry was "solved":

[W] hat Anne had provided us with was a kind of rationale, I mean we could justify picking on that particular day, at fourteen days, because of what Anne had taught us about the development of the embryo and the date after conception at which differentiation began. And once we'd got that into our heads, then in a way, everything flowed from that... [O]nce you got a regulatory line beyond which, if you passed beyond which, you committed a criminal offence, then you needed some justification for having the line - the essential thing was to have a line. And so we didn't say anything like that the embryo before fourteen days or fifteen days, was completely different from the embryo after the fifteen days, we just told the story of the development of the embryo, the appearance of the primitive streak, the subsequent differentiation, and the fact, too, that identical twins could form up to fifteen days, all that - there's a sort of combined rationale for having put fourteen days as the time. But we desperately needed something, which you could count the days on the calendar and simply say, now this embryo's got to be destroyed. It was no good having a developmental point, because either some other scientist would come up and find another developmental point that was more important. Or somebody might say, well this is a, you know, is a late developing embryo or something. It would be disputable. Whereas, days one to fourteen could be marked off and you could just draw the line at that point. So once that crucial issue was solved, then we just stuck to the line and we knew that was what was going to go into the Report. And the only dissenters in that of course, were as I say, the people who on religious grounds, thought that the life of a human embryo was sacred from day nought really. ${ }^{76}$

\footnotetext{
${ }^{74}$ Mary Warnock, "Anne McLaren as Teacher," International Journal of Developmental Biology 45, 3 (2001): 487-90, 488.

75 Ibid., 488, 490.

${ }^{76}$ Martin Johnson and Sarah Franklin interview with Mary Warnock, Feb. 2008, British Library Oral History Collection.
} 
This passage is significant for several reasons, including Warnock's description of the three key facts about "the story of the development of the embryo" that needed to be "got ... into our heads" so that "everything could flow from that." These three "developmental points" were "the appearance of the primitive streak," "the subsequent differentiation," and "that identical twins could form up to 15 days." These definitive transition points, however, are not sufficient grounds from which to "just draw the line," according to Warnock, and her language notably shifts from "a rationale" to "a combined rationale" midway through this extract, when the emphasis shifts to time: "We desperately needed something [with] which you could count the days on the calendar," she explains. "It was no good having a developmental point" on its own, because "it would be disputable." In contrast, "one to fourteen could be marked off and you could just draw the line at that point." In Warnock's view, "once that crucial issue was solved, then we just stuck to the line and we knew that was what was going to go into the Report."

When we interviewed Jenny Croft, also in 2008, she recalled the debate about the fourteen-day cut-off point and candidly described the logical and practical challenges to setting a firm cut-off point as she saw them from both emotional and logistical points of view:

You see, there isn't really a point at which the embryo becomes special. There really isn't. And therefore, justifying fourteen days is a bit tortuous, because you don't really want to say, we can't get them to last more than fourteen days, and that's what we're going for. Because then, when some clever person manages to keep them going for twenty-one, or whatever, you haven't got a justifiable position. So I think it's tortuous because it isn't really a justifiable position intellectually, you know, in the long run. [...] I think most people on the Inquiry, and indeed, most of our correspondence insofar as that reflects the general public, were quite happy with the Louise Brown scenario. They thought that was exciting. It's once you started moving away from that, that people's feelings became fuzzy. And I think that part of the idea of the Inquiry was to put some definite parameters on that fuzziness. Unfortunately, it is by its nature, quite a fuzzy subject. And people's feelings change.... And so this whole thing was a rolling process, I think, of public awareness. And I suppose the success of the Inquiry was that it established a kind of [level] playing field, and it is still the research end that people are predominantly anxious about. I think they're still anxious for the reasons that we were anxious, because there [aren't any] clear lines. And people have an emotional feeling that human embryos ought to be special but [when] asked to define why, they can't, unless as I say, you go for the ultra-logical Catholic position of saying that they're, you know, that they're special from beginning to end. But a kind of English pragmatism suggests that that can't be right. ${ }^{77}$

In her account of the "fuzziness" surrounding the question of the "point at which the embryo becomes special," Croft noticeably considers how people feel about the embryo as well as the logic behind various rationales for

\footnotetext{
${ }^{77}$ Martin Johnson and Sarah Franklin interview with Jenny Croft, 19 Mar. 2008, British Library Oral History Collection.
} 
justifying a cut-off point. Her description of the "tortuous" conflict between competing justifications does not just refer to the gap between an English pragmatism that favors support for scientific and technological progress and the "ultra-logical" Catholic doctrine that life begins at conception. She also means the gap between a general public enthusiasm for IVF catalyzed by the birth of Louise Brown and an anxiety of some Committee members and the public alike about embryo experimentation at a remove from the prospect of direct clinical benefits. Repeatedly, she refers to the gap between "emotional feeling" and an intellectual position regarding research on human embryos, which causes anxiety because of there are no "clear lines."

On the matter of "where to draw the line," Croft recalled a clear tension between the ultimate decision to draw a line at fourteen days based on definite criteria — including the emergence of a distinct individual — and the lingering awareness among Committee members that no amount of logical evidence could resolve "whether that was right or not":

Well, I think the committee accepted that a line had to be drawn at some point if they were going to allow any embryo research. And vaguely I can remember the occasion when the question of "when is individuality established?" [came up]. It's when you don't, where you may end up with a disc with just one primitive streak, two primitive streaks or no primitive streak, but until that time you can't tell whether it's going to be one or nil or, unusually, two. I think Mary Warnock herself intervened at that time. So you can't actually tell whether there's individuality until that moment.... I think it was that argument that persuaded the bulk of the committee that fourteen days was as good a cut-off point as any. But they always recognised that there were going to be arguments as to whether that was right or not. ${ }^{78}$

In this and many other descriptions of determining "where to draw the line" in the continuous process of embryonic development, ambivalence prevails: a line had to be drawn, and it had to be intellectually justified, assuage anxieties about uncontrolled research on embryos, and be "clear" to the general public, parliamentarians and policy makers, as well as to elite professional constituencies such as the Royal Society. As the arguments about the "embryo proper" and the formation of the embryonic disc that are so prominent in Papers 57 and 59 began to be bolstered by additional arguments about the emergence of an actual line on the embryo itself (the so-called "primitive streak"), the fourteenday point solidified into a credible basis for policy. But few believed that the "line" could be based on scientific facts by themselves; the issue was too complex for science alone to answer. The only fact (or rather formula) on which nearly everyone agreed was that if IVF and embryo research were to be allowed, definite limits had to be established, and guaranteed by the sovereign political body of Parliament. This need to combine authoritative scientific evidence with a multi-layered pragmatic form of reasoning in order to secure

78 Ibid. 
sufficient social consensus to legislate exemplifies the sociological complexity of successfully "translating" controversial bioscientific research.

\section{ONCLUSION}

Over the six years separating the Warnock Report's publication in June of 1984 and the passage of all sixty-four of the Inquiry's recommendations more or less unchanged into law in 1990, a prolonged public and parliamentary debate took place in the UK over "human fertilisation and embryology." The most highly contested issue remained the scope of permissible research on human embryos. Inevitably, critics challenged the key distinction on which the regulation was based, between what came to be known as the "pre-embryo" and the "embryo proper." Parliamentary opponents and Right-to-Life activists, joined by MPs, bishops, bioethicists, and some scientists, tried to pick apart the logic of the fourteen-day rule. ${ }^{79}$ For both Mary Warnock and Anne McLaren, the period from 1984 to 1990 was one of almost constant lobbying to enact the Human Fertilisation and Embryology Bill and establish a new Licensing Authority. Ultimately, these became the twin pillars supporting the "strict but permissive" climate for human embryonic cell-based experimentation in the UK that has now prevailed for nearly three decades.

In the conclusion to a 2018 comparative assessment of the legislation governing embryo research in the UK, Germany, and the United States, political scientists Sheila Jasanoff and Ingrid Metzler reaffirm the view of many that the "Warnock Consensus" has enabled controversial bioinnovation to proceed "markedly more smoothly [in the UK] than in other Western nations." 80 As a result, they assert, the UK has remained a uniquely wellregulated but scientifically progressive setting for translational bioscience.

One by one, the HFEA approved an array of practices and entities: derivation of hESCs [human Embryonic Stem Cells] from surplus IVF embryos, production of embryos for research through somatic cell nuclear transfer, genetic testing of in vitro embryos to ensure compatibility for treating a sick sibling, "human admixed embryos" in which animal egg cells are used to reprogram human somatic cells, and "mitochondrial donation." ... All of these innovations were subjected to extensive public consultation. Nevertheless, or perhaps precisely for this reason, none produced the public uproar or political deadlock that characterized comparable debates in Germany and the United States. ${ }^{81}$

The success of the Warnock Consensus carries valuable lessons regarding the translational process and its relationship to biogovernance generally.

\footnotetext{
79 See Wilson, Making of British Bioethics, chapter 4, for a detailed account of the vociferous critiques of the fourteen-day rule, especially just after the Warnock Report's publication.

80 Sheila Jasanoff and Ingrid Metzler, "Borderlands of Life: IVF Embryos and the Law in the United States, United Kingdom and Germany," Science, Technology and Human Values 43, 1 (2018): 1-37.

81 Ibid., 16, references removed.
} 
Particularly important is its social contract, or formula, of public consultation based on a high degree of trust that the general public will reach sensible conclusion when they are treated with respect and given time and information to think things through for themselves, combined with strict but pragmatic legislative limits. Sociological studies such as Charis Thompson's insightful analysis of the California Stem Cell Institute ${ }^{82}$ similarly suggest that more attention to the sociological dimensions of translational science will be vital to the delivery of successful innovations that repay the high investments in such products. For this same reason, it is important to revisit the translational histories of biotechnologies such as IVF, which, although often narrated as conventional stories of scientific discovery, can equally be understood as much more complex social processes of dialogic, iterative, and multilayered sociotechnical negotiation.

A more general conclusion to be drawn from the 1980s UK debate over IVF and embryo research is that the kinds of biological facts considered in the process of reaching social consensus around new techniques such as gene editing belong to a specific genre of translational knowledge, or biological reasoning, that must encompass broad social principles as well as specific scientific information. The Warnock Consensus confirms that biological and technological aspects of controversial research can be publicly debated in highly complex terms, just as the detailed sequences of post-fertilization development were explained in Annex A of Paper 59. One key lesson from the UK debate over "developmental landmarks" is that the public can adjust the level of technical detail they want to absorb. At least as important are the affective dimensions of new bio-techniques, as well as the pragmatic questions necessary to forging "workable" policy and governance: a consensus has to feel "alright enough," even if not completely sound. This means that aiming for a loosely based reasoning that is messy in places, rather than seeking neat, absolute lines, may be a better strategy for reaching consensus on "fuzzy" issues. Another implication is that "lines" need not be non-arbitrary in order to be "workable," and indeed, that lines are employed in arbitration not because they represent certainty but because they can be changed. This does not mean that "objective" scientific information loses all authority, but the Warnock process shows us how "pure" scientific facts can become more arbitrary in their ability to signify as public consultations over scientific innovation become more self-consciously pluralistic, multi-disciplinary, inclusive, critical, and reflexive.

It may be no coincidence that Mary Warnock and Anne McLaren were both women who understood and oriented their professional academic lives strongly in terms of public service. To them, "translation" could be understood

${ }^{82}$ Charis Thompson, Good Science: The Ethical Choreography of Stem Cell Research (MIT Press, 2013). 
to have many meanings, including the translation of scientific innovation into public goods, of scientific facts into public resources for consultation and debate, and of diverse opinions into a consensus that would be, in Warnock's words, "if not right then at least all right, to the largest number of people." 83 In translating across disciplines and sectors, between different professional communities, and the media and the general public, they led a process that delivered a remarkable legislative achievement unmatched anywhere since. By laying the foundations for successful national regulation of research on human fertilization and embryology, they delivered proof of principle for a unique system of biogovernance. The main critique of their reasoning - that the fourteen-day rule is arbitrary and based on a "spurious" biological distinction between the "pre-implantation period" and "the embryo proper"-misses the point that this very arbitrariness is not only inherent in scientific facts themselves, but a crucial feature of any laws, which must be changeable to endure and succeed. Herein lies the biology lesson for the future, in which social consensus will be the only reliable means of choosing which developmental landmarks we should follow.

An ironic final lesson, then, is that the critical "translation" that enabled the Warnock Consensus to succeed is also, in the longer term, its weakest link. By drawing a pragmatic but paradoxical line that both was and was not biological, the Committee implicitly devalued the social principles on which their consensus was actually based. These were that: (1) IVF and human embryo research should be allowed for the greater good of society; (2) if they were to be allowed then some line needed to be drawn; (3) the line had to be enforceable and clear to be workable and credible; and most importantly (4) such a line, in Warnock's words, "represented the moral idea of society." In the future, it may be possible to more explicitly base laws governing biological translation on sociological principles such as these, thus avoiding the disingenuity of providing a supposed basis for such laws in biological fact. As the Warnock Consensus has shown, "clear lines" can be established on the basis of inclusive and genuine debate leading to an agreed set of limits and conditions, and these limits and conditions can also be changed over time using the same process. If the fourteen-day rule is extended, providing a biological basis for that decision may be unnecessary. If that proves to be the case, another benefit of the Warnock Consensus will become clear, which is the proof-of-principle it has provided that workable legislation, even in such turbulent areas, is not only possible and feasible but can be enduring, iterative, reassuring, and stable, even if it is based entirely on social and civic dialogue.

\footnotetext{
83 Warnock, Nature \& Morality, 99. For a fascinating discussion of gendered cultures of science by one of Warnock's and McLaren's most observant contemporary feminist science studies scholars, see Hilary Rose, "Hand, Brain, and Heart: A Feminist Epistemology for the Natural Sciences," Signs 9, 1 (1983): 73-90.
} 
There are also lessons here regarding what is meant by "biological translation," and what can be learned from this context. To the extent biology is at once one of the most literal of languages - epitomized both by the idea of "biological facts" and "the facts of life" - and an overdetermined site of moral and social concern, it is at one level simply illogical to assume that "biology" can act as a firm arbiter in complex matters of governance, policy making, or the regulation of techniques such as gene-editing. To the extent that Mary Warnock drew on what we might call the "symbolic literalism" of biology, she did so knowing that it would enable her to deliver the crucial combination of both certainty and flexibility. By supplementing the logic of biology with days "you could count," she indicated that biological logic on its own was inadequate, and demonstrated that the art of translation does not simply reproduce the old entity, but creates a new one. These are lessons in logic and literalism that we need to learn if we are to ensure that complex new technological platforms such as human gene editing can be effectively regulated. For biological innovations such as these to be successfully translated, the kinds of sociological insights we can gain from the history of IVF will need to be seriously considered, fully understood, and widely shared.

\begin{abstract}
At a crucial meeting during their proceedings, on 9 November 1983, the sixteen members of Britain's influential Warnock Inquiry into Human Fertilisation and Embryology reached a key decision on how to base proposals for comprehensive legislation governing this largely uncharted territory. Famously, they chose the formation of the "primitive streak" in the early embryo as the basis for the fourteen-day rule that has now served as the global benchmark for experimental research in this area for nearly thirty years. Based on newly available archival material and interviews, this article offers a sociological account of the ways in which a specific translation of biological facts became the basis for an enduring social contract governing controversial bioinnovation in the UK. In particular, the combined roles of Committee Chair Mary Warnock and biologist Anne McLaren are examined in terms of how a decision, or "iterative settlement," was reached as to "where to draw the line" using specific "developmental landmarks" to establish a basis for legal regulation. Drawing from this analysis, I offer a broader argument concerning the sociology of biological translation and biogovernance that is germane to ongoing debates such that over how to limit CRISPRCas 9 gene editing. I contend also that we have yet to fully grasp the historical and sociological lessons to be drawn from the early histories of establishing governance over new forms of technological assistance to human reproduction, and in particular the formation of the "Warnock Consensus."
\end{abstract}

Key words: Warnock Inquiry, embryo research, UK legislation, translational biology, Mary Warnock, Anne McLaren 